\title{
Turismo rural: alternativa de melhoria para a agricultura familiar do sul de Minas Gerais
}

\author{
Rural tourism: alternative for the improvement of family agriculture in \\ the south of Minas Gerais (Brazil)
}

\section{Katiane Ribeiro Souza, Rosângela Alves Tristão Borém, Helena Maria Ramos Alves}

\begin{abstract}
RESUMO
A agricultura familiar no Brasil é responsável por mais de $40 \%$ do valor bruto da produção agropecuária, sendo um segmento de grande importância no meio rural. Contudo, as inovações tecnológicas, bem como as transformações ocorridas no campo nas últimas décadas vêm modificando as relações sociais de trabalho no meio rural, o que faz com que os produtores busquem alternativas de renda. . A região Sul de Minas Gerais, Mantiqueira de MInas, se destaca pelas paisagens montanhosas, condições edafoclimáticas agradáveis, rico patrimônio histórico, cultural e alimentar, além de ser a região que mais produz café no estado. Nos últimos anos a cafeicultura brasileira foi revalorizada pelo fortalecimento da agricultura familiar, plantio de produtos orgânicos e ações de conservação ambiental. Os objetivos deste trabalho são analisar as perspectivas do turismo rural associado à cafeicultura familiar, e identificar a potencialidade do turismo rural para o município de Poço Fundo, Minas Gerais, tendo como modelo o que já ocorre na cidade de Carmo de Minas, nesta mesma região, com a "Rota do Café Especial"; em Venda Nova do Imigrante (ES), região de montanhas com o Agroturismo; na Colômbia com o Turismo do Café e no Vale dos Vinhedos (RS) região vitinícola com o Enoturismo. Constatou-se que estes temas vêem se tornando cada vez mais importantes em função da necessidade de estudos que busquem alternativas de sustentabilidade para a agricultura familiar, garantindo a permanência dos agricultores familiares no campo e inibindo assim o êxodo rural. O turismo rural pode ser uma alternativa para garantir melhoria da qualidade de vida no campo, gerando renda e incentivando o desenvolvimento de produtos locais e a valorização de tradições culturais. Assim, essa forma de turismo pode proporcionar benefícios econômicos, sociais e ambientais não apenas para as populações que vivem nestas áreas mas para todos aqueles que a visitam e se favorecem dos produtos e atrativos da região.
\end{abstract}

PALAVRAS-CHAVE: Sustentabilidade; Cafeicultura Familiar; Turismo Rural.

Página 990 Revista Brasileira de Ecoturismo, São Paulo, v.6, n.5, nov 2013-jan 2014, pp.990-1015.

Sociedade Brasileira de Ecoturismo. Rua Dona Ana, 138, Vila Mariana, São Paulo, SP - Brasil. E-mail: rbecotur@sbecotur.org.br; Tel. (55-II) 99I96-7685 


\section{ABSTRACT}

Family farms in Brazil are a segment of great importance in rural areas, responsible for more than $40 \%$ of total agricultural production. However, technological innovations as well as changes in the fields over the past decades have changed the social relations of workers in rural areas, forcing producers to seek alternative sources of income. Southern Minas Gerais, in the Southeast region of Brazil, is characterized by mountainous scenery, pleasant climatic conditions, rich history, culture and cuisine, besides being the state's largest coffee producing region. In recent years the Brazilian coffee crop has increased in value because of the strengthening of family farming, cultivation of organic products and actions for environmental conservation. The objectives of the present study are to analyze the perspectives for rural tourism associated with small family coffee farming and identify the potential of rural tourism in the region of Poço Fundo, Minas Gerais, taking as models what is already happening in the city of Carmo de Minas, in the same region, with the "Special Coffee Route"; in Venda Nova do Imigrante (ES), a mountainous region with agritourism; in Colombia with Rural Coffee Tourism; and in the Valley of the Vineyards (RS) region with wine tourism. It was found that the subject of rural tourism has become increasingly important due to the need for studies that seek alternatives for sustainable family farming, ensuring the stability of family farmers in the fields and thereby inhibiting the rural exodus. Rural tourism can be an alternative to ensure improved quality of life in the country, generating income and encouraging the development of local products such as handicrafts. Thus, this form of tourism can provide economic, social and environmental gains to people living in these areas and to all those who promote the products and attractions of the region.

KEYWORDS: Sustainability; Rural Tourism; Family Farming.

\section{Introdução}

O Sul de Minas Gerais faz parte das doze Regiões de Planejamento do Estado, cuja população de aproximadamente dois milhões e quatrocentas mil pessoas está concentrada em seus 155 municípios. Desse total, 530 mil residem no meio rural. A região se destaca em âmbito nacional por suas condições naturais, rico patrimônio histórico, cultural e agro alimentar. Sua localização geográfica privilegiada facilita o cultivo de diferentes tipos de cafés, que são produzidos em regiões com aspectos edafoclimáticos, socioeconômicos e culturais singulares.

O café constitui um produto de grande peso na agricultura do Brasil, principalmente no estado de Minas Gerais, maior produtor nacional, onde a cultura historicamente tem se apoiado em bases familiares, técnicas em constante evolução e tradições socioculturais solidamente enraizadas. O café produzido na região representa uma das mais importantes fontes de renda para a economia brasileira, compondo o segundo produto na pauta das exportações agrícolas do País (GOMES; ROSADO, 2005).

O Sul de Minas Gerais é a região que produz a maior quantidade de café do estado, sendo que alguns de seus municípios recebem maior destaque pelas 
conquistas em concursos de qualidade de café reconhecidos nacional e internacionalmente, o que agrega valor ao produto local e o faz mais competitivo.

Os cafés Gourmets em sua grande maioria produzidos em áreas de montanhas do Estado vêm conquistando notoriedade em nível mundial. Neste contexto, destacase entre os municípios produtores de café da região Sul de Minas, o município de Poço Fundo, que além das condições edafoclimáticas favoráveis à produção de cafés especiais, apresenta outros fatores importantes como o cooperativismo solidamente estabelecido, as certificações de comércio justo, a sustentabilidade da cafeicultura familiar com respeito ao ambiente, os produtos orgânicos e mais recentemente, a possibilidade do estabelecimento de uma Indicação Geográfica, na modalidade de Indicação de Procedência, que está reaquecendo o comércio de café a níveis satisfatórios para os produtores (VIEIRA et al., 2011; SILVEIRA, 2009). A partir dos anos 1990, Poço Fundo passou a ser considerado como município de referência mundial na produção orgânica de café com certificação de comércio justo através do trabalho da Cooperativa dos Produtores Familiares de Poço Fundo e Região COOPFAM (PEDINI, 2005).

A agricultura familiar é um segmento de grande importância no meio rural brasileiro, é responsável por mais de $40 \%$ do valor bruto da produção agropecuária. No entanto, as inovações tecnológicas, bem como as transformações ocorridas no meio rural nas últimas décadas vêm modificando as relações sociais de trabalho. Isso tem feito com que os produtores busquem rendas alternativas de forma a compensar os baixos lucros provenientes do trabalho do meio rural.

Em países em desenvolvimento como o Brasil, os cafeicultores têm aceitado preços cada vez menores, assim, muitos vivem na pobreza, sem segurança, saúde e sustentabilidade em seu meio. Porém, mesmo com a crise no setor cafeeiro, a cafeicultura brasileira nos últimos anos foi revalorizada pelo fortalecimento da agricultura familiar, pelo plantio de produtos orgânicos contendo certificações e pela preocupação com a preservação ambiental.

Associada a esta tendência, existe também um mercado crescente nos países desenvolvidos, que busca alternativas para melhores preços e condições de comercialização de produtos agrícolas provenientes de países em desenvolvimento (KOTLER, 1998; MACHADO, 2005).

A oferta de produtos alimentícios certificados, orgânicos e produzidos de forma sustentável, vem como resposta à crescente demanda dos consumidores por estes tipos de alimentos. Mesmo com maiores preços no mercado, uma parcela de consumidores escolhe estes alimentos orgânicos e isto está reaquecendo o comércio de café a níveis satisfatórios para os produtores.

Além disso, vê-se a necessidade de estudar alternativas que garantam a permanência dos agricultores familiares no campo e com isso impedir o êxodo rural. $O$ turismo rural pode ser uma dessas alternativas ao garantir uma melhoria da qualidade de vida no campo, gerando renda, incentivando o desenvolvimento de produtos locais como artesanatos e agregando valor a seu modo de vida. Assim, essa forma de

Página 992 Revista Brasileira de Ecoturismo, São Paulo, v.6, n.5, nov 2013-jan 20I4, pp.990-I0I5. 
turismo pode proporcionar benefícios econômicos, sociais e ambientais para os municípios e a todos aqueles que se favorecem dos produtos e atrativos da região.

O turismo rural pode ter a função de indutor de desenvolvimento e de conservação, pois incentiva e até mesmo possibilita a conservação, manutenção e valorização do patrimônio histórico, cultural e natural da região onde está sendo explorado. Pode também proporcionar benefícios à população local, com melhorias na infraestrutura e nos serviços oferecidos, além de criar mercado para os produtos agrícolas com referência geográfica (LIMA FILHO et al., 2004). Em contrapartida, ele pode trazer transtornos à comunidade por meio da influência dos turistas, como por exemplo, os impactos sobre o meio ambiente, o aumento do custo de vida $\mathrm{e}$ descaracterização de determinados traços culturais da sociedade local.

Para os turistas que saem dos grandes centros e estão ligados ao stress urbano, à poluição, à violência e alimentação de pouca qualidade, estar em um lugar com atrativos típicos de uma específica região como os propostos pelo turismo rural é uma experiência única. Além dos produtos de qualidade, os turistas podem usufruir do clima da região, da tranquilidade do ambiente e se integrar ao mundo do agricultor familiar e em seu ritmo de vida.

Com este intuito, tem-se buscado incentivar a criação do turismo ligado à atividade cafeeira de base familiar de Poço Fundo, tendo como base o que já ocorre no município de Carmo de Minas, também localizado na região Sul de Minas Gerais, denominada "Rota do Café Especial". No percurso dessa rota os turistas conhecem o processo de produção e rastreabilidade do café, caminham pelas plantações, visitam o pátio de secagem, mirantes, aprendem sobre a história local e sobre o produto Café. Os turistas têm o privilégio de apreciar o café em um típico casarão colonial, que funciona também como um museu dentro da fazenda visitada (TORGA, 2011). Em acompanhamento ao café Gourmet, os visitantes podem experimentar deliciosos quitutes típicos da região.

Esta é uma realidade que também acontece com o enoturismo, turismo rural que tem como base a produção de uva e vinhos e já é praticada com sucesso no Sul do Brasil. Uma referência importante deste segmento é a região do Vale dos Vinhedos no Rio Grande do Sul, que já possui uma Indicação de Procedência para o vinho e tem ampliado as atividades do turismo rural e tornado seus produtos e serviços cada vez mais diferenciados e valorizados. O que tem sido observado e documentado é o crescente prestígio da região, que passou a ser conhecida no cenário nacional e internacional, com benefícios diretos para os produtores e agroindústrias locais (TONIETTO, 2008). Esta possibilidade, que no caso da área da Indicação de Procedência Vale dos Vinhedos já é realidade, evidencia-se como alternativa promissora que irá favorecer o relacionamento dos agricultores com aqueles que vivem em lugares de grande concentração populacional, com crescentes inconvenientes ligados ao stress urbano, ao transporte, à poluição, à violência, à alimentação inadequada ou à saúde. O diálogo entre estes dois mundos pode levar a um reconhecimento de qualidades no modo e ritmo da vida rural (SILVEIRA, 2009).

Andrade e Moss (2012) quando discutem a importância do Turismo do Café na Colômbia, destacam que Minas Gerais mesmo sendo a maior região produtora de 
café, localizada no maior país produtor e segundo maior consumidor mundial, vem desenvolvendo sua identidade turística sem dar ao produto café o devido lugar de destaque.

Considerando que a região Sul de Minas está próxima às metrópoles São Paulo, Rio de Janeiro e Belo Horizonte, e diante do potencial do turismo rural, avalia-se que este segmento pode se transformar em uma atividade promissora na região. Para tanto é imprescindível o desenvolvimento de projetos turísticos, adequados à agricultura local, que visem favorecer economicamente tanto os cafeicultores como o comércio urbano. Há necessidade de acrescer maiores esforços em pesquisas e assim conhecer melhor estas potencialidades, seus desafios e os possíveis impactos, para que o turismo se torne uma opção viável de desenvolvimento para as áreas rurais.

Dessa forma os objetivos do presente trabalho foram analisar as perspectivas do turismo rural associado à cafeicultura familiar e identificar a potencialidade turística rural para a região de Poço Fundo, Minas Gerais, tendo como modelo o que já ocorre na cidade de Carmo de Minas, nesta mesma região, com a "Rota do Café Especial", em Venda Nova do Imigrante (ES), região de montanhas com o Agroturismo, na Colômbia com o Turismo do Café e no Vale dos Vinhedos (RS) região vitivinícola com o Enoturismo.

Para tanto, foi realizada uma caracterização ambiental do município, com a utilização de geotecnologias para o mapeamento do uso e ocupação das terras e produção de outros mapas temáticos de interesse. Foi realizado um levantamento da história da cafeicultura na região e visitas para contato com cafeicultores, técnicos e pessoas da comunidade ligadas a atividades de turismo rural.

\section{O Panorama brasileiro do café e seu papel econômico}

O café é historicamente estratégico para as exportações brasileiras. Mesmo tendo caído em importância relativa no quadro geral das receitas cambiais, o produto tem garantido ao Brasil o primeiro lugar como produtor e exportador e o segundo posto como país consumidor no mercado internacional (COELHO, 2005). Além de sua importância histórica na economia nacional, a relevância social da cafeicultura é evidente, tanto como fixadora de mão de obra no campo quanto como geradora de empregos nos meios rural e urbano.

O agronegócio café brasileiro abrange cerca de 1900 municípios produtores, 370.000 cafeicultores, 1 milhão de trabalhadores rurais e mais de 8 milhões de pessoas que estão ligados direta e indiretamente à cadeia produtiva do café (KHATOUNIAN; SOARES-JÚNIOR, 2005; CONAB, 2012). No entanto, desde sua introdução, a cafeicultura brasileira tem passado por ciclos históricos de apogeu e declínio que estão relacionados a aspectos sociais e econômicos, mas também ambientais.

A cafeicultura brasileira é representada por cerca de trezentas mil propriedades de extensões diversas, dentre as quais, dois terços são de pequenos cafeicultores 
que produzem sob normas e critérios de sustentabilidade baseado no tripé: social, ambiental e econômico, é que se representa a cafeicultura brasileira. Os investidores em cafés finos ou gourmets no Brasil têm o privilégio de poder escolher o princípio de processamento mais apropriado às necessidades de seus clientes (mercado interno e externo) em razão do clima adequado durante o período da colheita.

No período de 2002 a 2007, o Brasil exportou cerca de 161 milhões de sacas de café. Em 2007, o Brasil exportou 28,1 milhões de sacas de café, representando aumento de 2,61\% com relação ao ano anterior. A receita de 2008 foi de US\$3,3 bilhões. Em 2008 foram comercializados mais de 8 milhões de sacas de cafés certificados, o que equivale a $6 \%$ do dispêndio mundial. A safra 2012 deve chegar a 50,45 milhões de sacas de $60 \mathrm{~kg}$, de acordo com o segundo levantamento feito pela Companhia Nacional de Abastecimento (CONAB, 2012). O resultado é $16 \%$ maior que 0 da safra anterior (43,48 milhões de sacas) e supera o recorde do ciclo 2002/2003, quando foram produzidos 48,48 milhões de sacas.

O café brasileiro é disputado por países como Alemanha, Estados Unidos, Itália, Japão e Bélgica. Além de maior exportador o país também figura como segundo maior consumidor desta bebida, ficando atrás somente dos Estados Unidos (TEIXEIRA, 2008; ABIC, 2009, 2012). De acordo com Gabriel Carvalho Dias, presidente da Associação Brasileira de Cafés Especiais (BSCA), a demanda por cafés especiais cresce muito acima do café convencional, cerca de $15 \%$ ao ano contra menos de $2 \%$ do comum.

O crescimento da produção de cafés de qualidade no Brasil tem estimulado não só o mercado internacional, mas também o interno. Quando aconteceu o $1^{\circ}$ Prêmio Brasil de Qualidade do Café para Expresso, há 18 anos, este foi organizado e patrocinado pela torrefadora italiana Illycaffè e duvidava-se que o Brasil possuía cafés de alta qualidade (BSCA, 2009). O café não é remédio, mas a comunidade médicocientífica já considera a planta como funcional (previne doenças, mantendo a saúde) ou mesmo nutracêutica (nutricional e farmacêutica). Isso por que o café não possui apenas cafeína, mas também potássio, zinco, ferro, magnésio e diversos outros minerais (COOPERCAM, 2009).

\section{O Panorama da cafeicultura de Minas Gerais}

Minas Gerais destaca-se no cenário brasileiro como o maior produtor, com uma participação de 50,99\% do café produzido no país (CONAB, 2012). Apesar de ser o Estado de maior relevância para a produção do país, Minas ainda não possui todos os dados necessários para subsidiar as atividades de planejamento de sua cafeicultura e garantir a sua sustentabilidade e competitividade. Por sua extensão territorial e variação ambiental a cafeicultura mineira tem sua produção distribuída em quatro ambientes principais, constituídos pelas regiões Sul de Minas (Sul/Sudoeste), Matas de Minas (Zona da Mata/Rio Doce), Cerrados de Minas (Triângulo Mineiro/Alto Paranaíba) e Chapadas de Minas (Vale do Jequitinhonha/Mucuri) (BARBOSA, 2009).

O café compõe um dos principais produtos da pauta de exportações brasileiras, sendo o Sul de Minas Gerais uma das regiões mais significativas na produção. Nesta 
região produz-se $53 \%$ da produção estadual, $25,2 \%$ da produção nacional e o café corresponde a $70 \%$ da renda das propriedades rurais (COELHO, 2005). Em meio às áreas cafeeiras desta região, existem aquelas com características fisiográficas extremamente adequadas à produção de cafés especiais. Estas regiões caracterizamse por áreas com grandes elevações, altitude variando entre 700 a 1.200 metros, temperatura amena, sujeitas a geadas moderadas e capazes de produzir um café de excelente qualidade de bebida (RIBEIRO et al., 1999).

Muito mais que uma simples delimitação geográfica, o Sul de Minas se transforma, cada vez mais, em um lugar privilegiado para o descanso e recreação daqueles que habitam grandes regiões metropolitanas. A região é associada a um rico e diversificado patrimônio agro alimentar, gastronômico, cultural e turístico, onde se destaca a cafeicultura, que precisa ser mais bem aproveitado em favor das comunidades locais. Os diferentes cafés produzidos no sul de Minas estão relacionados a microrregiões com variações edafoclimáticas que fazem com que a qualidade do café se expresse de maneiras distintas. Os diferentes ambientes cafeeiros, por sua vez, correspondem a aspectos socioeconômicos e culturais muito particulares, geradores de identidades coletivas muito próprias, que são evidências claras da existência de várias representações territoriais (MARQUES et al. 2007).

Poço Fundo, município objeto de estudo neste trabalho, também tem como principal atividade agrícola a cafeicultura, que se encontra em um território diferenciado em termos do ambiente e da qualidade do café produzido. De acordo com Pedini (2005) a cafeicultura de Poço Fundo é de grande relevância, com um número cada vez maior de estabelecimentos produzindo café orgânico, em sistemas agrícolas que se caracterizam por uma diversidade de técnicas e a multiplicação dos processos inovadores de comercialização (comércio commodity, comércio justo e solidário, exportação de café orgânico para a Europa, Estados Unidos e Japão).

\section{Agricultura familiar: Conceitos e demandas}

A agricultura familiar no Brasil corresponde a mais de $80 \%$ dos estabelecimentos rurais, emprega em torno de 13 milhões de trabalhadores, entre estes 1 milhão como assalariados, permanentes ou temporários (MARTINS, 2003). O pensar em agricultura familiar, contudo, é recente e até poucos anos atrás se falava em pequena produção, pequeno agricultor, "produção de baixa renda", de subsistência e camponês (DENARDI, 2009).

Estudos no campo da Antropologia, da Economia, Sociologia e também da Geografia têm ressaltado a importância econômica, cultural e política da agricultura familiar no Brasil e no mundo. Estudos como os de Mendras (1978), Abramovay (1998), Lamarche (1993), Wanderley (1999), Mendes (2005) e Saquet (2009) enfatizam a importância da agricultura familiar na produção de mantimentos básicos, que garantem a subsistência e a reprodução da própria família, contribuindo para a geração de emprego e renda no meio rural, tornando os preços acessíveis e justos ao consumidor e produtor, respectivamente, uma vez que os atravessadores fossem eliminados da cadeia produtiva. 
Os agricultores familiares podem se enaltecer pelos valores históricos de suas terras e famílias como, por exemplo, os aspectos culturais que Ihes são próprios, repassados de pai para filho, passados de geração a geração, fazendo com que essas unidades produtivas sejam terras de vida e de reprodução de cada família.

Lamarche $(1993$, p.) realizou um estudo sobre a agricultura familiar em diferentes países e o ponto básico do enfoque de sua pesquisa parte da seguinte constatação:

Sejam quais forem os sistemas sócio-políticos, as formações
sociais ou as evoluções históricas, em qualquer lugar do mundo
onde um mercado organize as trocas, a produção agrícola é
sempre, em grande ou pequena escala, garantida por explorações
familiares, ou seja, por explorações nas quais as famílias
participam da produção.

A agricultura familiar busca o paradoxo da perpetuação do tradicional, com a produção e recuperação do meio simultaneamente, garantindo assim, a qualidade de vida para quem trabalha e produz no campo. Os agricultores têm as famílias como forças básicas para produção. Nesta categoria encaixam-se também aqueles que utilizam o trabalho contratado, seja ele eventual ou permanente, desde que não sobreponha ao esforço do trabalho familiar. Os agricultores familiares têm acesso estável a terra, seja em forma de propriedade, ou mediante algum tipo de usufruto (meeiro). Também são caracterizados pela auto-subsistência combinada com a vinculação ao mercado, eventual ou permanente, além da autonomia de tomar decisões sobre o que, como e quando plantar (SILVA, 2002; FERNANDES, 2009).

Dentro do agronegócio brasileiro, observa-se que a agricultura familiar é um setor estratégico para a sustentação e recuperação de empregos, para a redistribuição da renda e para garantir alimentação sustentável para a população do país $(\mathrm{SCHUCH}$, 2009).

O Governo Federal lançou em setembro de 2003 o Programa Nacional de Fortalecimento da Agricultura Familiar - o PRONAF, que tem uma linha de crédito chamada "PRONAF Turismo Rural", cujo objetivo é apoiar os agricultores familiares que almejam programar atividades turísticas no âmbito das unidades familiares de produção (MDA, 2009). O Ministério do Desenvolvimento Agrário (MDA) lança a partir da safra 2009/2010 o Selo da Agricultura Familiar. Este selo chegará aos consumidores através dos alimentos identificados como: "Aqui tem agricultura familiar". O MDA concede 0 selo a partir da adesão voluntária dos produtores. Espera-se que este Selo valorize a produção agrícola familiar, permitindo que o consumidor saiba a origem desses alimentos diferenciados, produzidos em meio rural justo e por um cultivo sustentável (MDA, 2009).

O Selo da Agricultura Familiar terá validade de cinco anos e será concedido para a identificação de produtos. Além de garantir mais informações e segurança alimentar ao consumidor, estimulará a economia nacional a partir da ampliação da comercialização de produtos da agricultura familiar. O principal critério para adesão ao Selo estabelece que $51 \%$ da principal matéria-prima do produto tenha origem na 
agricultura familiar. O que caracteriza os estabelecimentos familiares, conferindo-Ihes vantagem competitiva é a gestão familiar das atividades, a sustentabilidade, a multifuncionalidade, a diversidade de produção e de tipos de rendas (MDA, 2009).

\section{Indicação Geográfica (IG): Aquecendo o Turismo Rural}

A Indicação Geográfica (IG), na modalidade de Indicação de Procedência (IP), constitui uma demanda dos agricultores familiares que almejam agregar valor aos produtos e serviços de suas propriedades e municípios. De acordo com o guia IG MAPA, a indicação geográfica, constitui um direito de propriedade intelectual autônomo, a exemplo de uma patente ou de uma marca. Este direito é reconhecido nacional e internacionalmente. A IG é um selo distintivo composto por um nome geográfico e protegido por lei. Este nome geográfico indica uma origem (um local ou uma determinada região), que identifica e distingue um produto ou serviço. É um direito privativo (e exclusivo) de uso coletivo, quer dizer, é restrito aos produtores e/ou prestadores de serviço estabelecidos no local e que estão de acordo com as regras estabelecidas (MAPA, 2009).

A legislação brasileira prevê para produtos e serviços agropecuários duas espécies de proteção como Indicação Geográfica (Lei n 9279/96 - LPI, artigos 177 a 179):

a) Denominação de Origem (DO) - nome geográfico de país, cidade, região ou localidade de seu território, que designe produto ou serviço cujas qualidades ou características se devam exclusiva ou essencialmente ao meio geográfico, incluídos fatores naturais e humanos.

b) Indicação de Procedência (IP) - nome geográfico de um país, cidade, região ou uma localidade de seu território, que se tornou conhecido como centro de produção, fabricação ou extração de determinado produto ou prestação de determinado serviço (MAPA, 2009).

O Vale dos Vinhedos foi o primeiro local a ter Indicação Geográfica no Brasil, já reconhecida até na União Européia. A cadeia vitivinícola foi pioneira ao trazer membros do Instituto Nacional da Propriedade Industrial (INPI), órgão responsável pelo reconhecimento da propriedade industrial conferida pela IG e da equipe responsável pelas IGs do Ministério da Agricultura, Pecuária e Abastecimento (MAPA) para conhecerem as associações e as vinícolas que se prepararam para obter esta qualificação para os vinhos e espumantes da Serra Gaúcha (ZANELLA, 2008).

A obtenção da Indicação de Procedência, além de garantir a proteção do produto e da sua origem atribuída, poderá alçar a cafeicultura desta configuração espacial ao pioneirismo em termos da conciliação da produção agrícola com as vocações territoriais. Neste caso, as dimensões tais como identidades culturais, iniciativas sociais, aptidões ecológicas e ações ambientalistas passam a ser reconhecidas como funções essenciais. Aqui vale o destaque para outra característica essencial, que é o potencial socioeconômico da produção familiar local em áreas de 
montanhas (familiar de montanha), que se traduzirá em trunfo vigoroso (VIEIRA et al., 2011, p.).

Firma-se então, um ambiente institucional adequado para a promoção da agricultura familiar e do turismo Rural, que acredita na possibilidade de construir um modelo de desenvolvimento que persisti a reduzir as disparidades sociais e econômicas no País. É um processo que vem unificando, de forma crescente, vários seguimentos populacionais (CARVALHO, 2009).

\section{Turismo Rural: Conceitos, Demandas e Potencialidades}

Em termos de vendas, geração de emprego e receitas, o setor de turismo tem sido considerado um dos mais significativos para a economia mundial, mesmo quando comparado a muitas indústrias de manufaturas e outros serviços (LAGE; MILONE, 2000).

No período de 1950 a 1992, o setor apresentou uma média de crescimento econômico mundial de 7,2\% ao ano. Especialmente na década de 1990, foi considerado o setor mais significativo da economia mundial, apresentado, na sua primeira metade, um crescimento entre $3 \%$ e $3,5 \%$ e, na segunda metade, de $4 \%$ e $5 \%$. A previsão é de que, até o ano de 2010, sejam identificados 937 milhões de turistas, representando um crescimento de 100\%, entre os anos de 1990 a 2010. Na economia, em 1999, a atividade contabilizou um aumento de $4,8 \%$ para $7,8 \%$ na renda, gerando 212 milhões de empregos e movimentou cerca de US $\$ 3,8$ trilhões, representando $11 \%$ do PIB global (MILONE; MILONE, 2000).

Segundo Sheyvens (2002), no período de 1950 a 1970, o turismo convencional ou de massa foi considerado, particularmente para os países emergentes, um meio de promoção de crescimento econômico, de alcance da modernização e uma forma de enfrentar os reflexos advindos do processo da globalização. O mesmo autor afirma que o sistema turístico passou a ser visto como um meio de produção e consumo para se alcançar a modernização. Surge então um novo modelo de produção e consumo de turismo denominado pós-moderno, em que a idéia defendida é a de harmonizar a satisfação da necessidade de conservação e preservação de aspectos ambientais e culturais com as necessidades econômicas (SHEYVENS, 2002).

A partir daí, o turismo no espaço rural na Europa passou a ser visto, em sua fase inicial, como uma proposta alternativa no contexto do turismo. No entanto, ele não representa nem uma novidade e nem a substituição do turismo convencional de praia e sol e de massa, visto que esta modalidade acompanha a evolução do turismo desde o início. Na verdade, é mais uma modalidade demandada por um segmento de mercado que defende aspectos como a valorização e a conservação das características naturais e históricas das propriedades e regiões, a preservação dos valores humanos, além de aliar ao meio rural, características diferenciadoras como a nostalgia e a tranqüilidade proporcionadas pela vida no campo. Se bem planejado, o turismo rural pode ser uma estratégia de suplementação ou complementação dentro da propriedade rural, permitindo a estabilidade da organização e a integração das atividades tradicionais. Além disso, permite a interação entre o setor rural e urbano, ou seja, a inter-relação 
social, envolvendo pessoas de diferentes espaços, o que é considerado positivo (TAGLIARI; FRANCO, 1994).

O turismo no espaço rural tem sido considerado não apenas uma solução para os problemas decorrentes da gestão do turismo de massa, mas também uma das soluções para os problemas de desequilíbrios decorrentes do crescimento econômico mundial. Se por um lado, nunca houve tanta riqueza e fartura no mundo, por outro lado esse crescimento gerou a miséria, a degradação ambiental, a marginalização de algumas regiões, de pequenas e médias empresas e as desigualdades. Todos esses problemas geraram incertezas quanto ao futuro de espaços e suas populações, limitando o desenvolvimento (CAVACO, 2001). Segundo Beni (1998), Turismo é eminentemente um acontecimento social que, ao originar uma série de prestezas, como transporte, alojamento, recreação e outras, as faz gerar outra série de efeitos sobre o meio ambiente em que se desenvolvem e que podem ser de caráter econômico, social, cultural e até ecológico. Conceitualmente, em um destino turístico, tem-se concentração de instalações e serviços planejados para satisfazer às necessidades dos turistas (COOPER et al., 1996; CÓRNER, 2001).

O turismo rural acontece em vários locais do Brasil e do mundo e de diferentes maneiras. No Brasil, acontece expressivamente em várias regiões (BRASIL, 2004). No Sudeste, por exemplo, na região de montanhas do Espírito Santo, mais especificamente na cidade de Venda Nova do Imigrante, costumava-se receber visitas. Na verdade, os visitantes iam às fazendas para colher frutas e verduras e as famílias de agricultores gostavam dessas visitas. Com o surgimento do Turismo Rural e do Agroturismo essa realidade mudou. $O$ trato confinado do gado, a produção de queijos e o manejo agrícola tornaram-se atrações turísticas que agregaram valores às fazendas dos agricultores familiares, com qualidade e variedade nos produtos, que então passaram a estruturar os destinos turísticos de forma que turistas e agricultores se beneficiassem (PIN; CARNIELLE, 2005; ALVES; PAGLIARUSSI, 2006; ZANDONADI; FREIRE, 2012).

Outra localidade onde o turismo rural recebe destaque é do Vale dos Vinhedos, no Sul do Brasil, região vitivinícola onde os agricultores familiares investem no cultivo da uva e produção de vinhos finos, em rotas turísticas e outras denominações criadas para tais. O turista aproveita do clima da região propicio para os parreirais, assiste ao processo de produção e colheita, aprecia o processo de plantio até a colheita da uva (TONIETTO, 2008).

Os impactos dos exemplos citados acima foram positivamente expressivos, tanto para os agricultores e comunidade local, quanto para a região e turistas. A região beneficia-se com maior giro de capital e demanda que atribuem valores aos destinos. Para a população local, mais emprego e aumento na renda, além do intercâmbio cultural proporcionado. Para os turistas, o acréscimo de valores culturais, alimentícios e a tranqüilidade dos destinos, se refletem em maior qualidade de vida, que os tira do stress urbano. Porém, como em qualquer segmento há desvantagens. Pode surgir a descaracterização da cultura local e do ambiente e o impacto ambiental nas propriedades, pelas novas construções e muitas vezes pela imigração de turistas.

Página 1000 Revista Brasileira de Ecoturismo, São Paulo, v.6, n.5, nov 20I3-jan 2014, pp.990-I0I5. 
O turismo rural ganhou destaque em discussões sobre alternativas para agricultura familiar, quando se discutiu problemas como o de baixa renda e desemprego. Visão esta que influenciou as políticas públicas, a ponto de o Governo Federal lançar em setembro de 2003 o Programa Nacional de Fortalecimento da Agricultura Familiar - o PRONAF, que tem uma linha de crédito chamada "PRONAF Turismo Rural", aonde o objetivo é apoiar os agricultores familiares que almejam programar atividades turísticas no âmbito das unidades familiares de produção. Conforme explicado pelo Ministro de Desenvolvimento Agrário, Miguel Rossetto, este programa visa o desenvolvimento rural sustentável, com a agricultura familiar e as atividades agropecuárias como forças em rumo ao desenvolvimento, que busca explorar o potencial turístico enquanto atividade capaz de preservar o meio ambiente, valorizar e resgatar a cultura local, além de gerar emprego e renda (MDA, 2009).

De acordo com a LEI №. 15.143 - 31/05/2006 Publicado no Diário Oficial №. 7238 de 01/06/2006 - Art. 1ำ- Turismo Rural na Agricultura Familiar (TRAF) são todas as atividades turísticas que ocorrem na unidade e produção dos agricultores familiares que mantêm a economia típica da agricultura familiar. Dispostos a dar valor, respeitar e dividir seu modo de vida, o patrimônio cultural e natural, ofertando produtos e serviços de qualidade e proporcionando bem estar aos envolvidos. Já o Art. $2^{\circ}$ expressa quais são as atividades do TRAF, que considera a comercialização de produtos alimentícios in natura de origem local, de produtos de origem animal, venda de artesanatos, prática de produção com aproveitamento de produtos, resíduos ou não, seja de origem vegetal, animal ou mineral, produção rural. Onde as atividades produtivas da propriedade são utilizadas como atrativos, por meio de demonstrações sobre as técnicas de produção, onde o turista pode interagir com o meio. Como também as atividades de educação ambiental, serviços de lazer, que incluem cavalgadas, caminhadas pela propriedade, serviços de alimentação, como restaurantes, cafés coloniais, serviços de hospedagem, como pousadas, hospedarias, serviços ambientais em áreas naturais, eventos, pesquisas tecnológicas e patrimônio histórico, por todos esses seguimentos e atividades se justifica o surgimento do TRAF (TRAF, 2009).

Esta rede já é uma realidade em vários estados brasileiros, valoriza famílias rurais que vivem do trabalho no campo e que vêem na exploração da atividade turística a possibilidade do aumento de sua renda. Diante deste contexto, e vislumbrando também a possibilidade do turismo rural fortalecer a cultura e a preservação do meio ambiente, o Ministério do Desenvolvimento Agrário - MDA passou a motivar o desenvolvimento de ações de capacitação de agricultores nesta área, tendo, no estado do Paraná, encontrado como parceiros a divulgar o turismo como alternativa para diversificação do trabalho agrícola, o Serviço Social Autônomo ECOPARANÁ/SETU, Emater/Seab e a Fundação Terra, com o apoio das prefeituras municipais. Neste trabalho, agricultores, agentes de desenvolvimento e técnicos de todo Paraná envolveram-se em cursos, reuniões, eventos e excursões técnicas, despertando neles o interesse em fortalecer cada vez mais esta frutífera relação entre turismo e agricultura familiar (ECOPARANA, 2009).

As potencialidades da atividade de Turismo Rural na Agricultura Familiar são, por exemplo, o auxílio na permanência das pessoas da família na unidade de produção, 
o rompimento do isolamento dos agricultores, a diversidade de produtos e serviços ofertados, como também a diversidade de experiências. Já os limites são as baixas condições financeiras dos agricultores para inserção no mercado, localização geográfica dos empreendimentos, problemas decorrentes da sazonalidade de visitas aos empreendimentos, geração de renda e de emprego. Assim, as potencialidades do turismo rural na agricultura familiar estão condicionadas, por um lado, pela organização de circuitos turísticos adequados, tanto em termos das tradições culturais e das condições naturais como das dinâmicas locais e regionais com suas características específicas (MATTEI, 2003).

\section{A cafeicultura e sua relação com o turismo}

Discute-se a relação entre o café e o turismo sob o aspecto estético em que se fala da beleza dos cafezais, cobrindo vales e montanhas, criando assim paisagem para o turismo contemplativo, e também na oferta de um produto de boa qualidade para degustação, com aroma e sabor diferenciados, além da qualidade de vida proporcionada para todos os envolvidos (CARNIELLI; MELO, 2005; ALVES; PAGLIARUSSI, 2006; ZANDONADI; FREIRE, 2012).

Menção também é feita a eventos do setor, a exemplo do "Cup of Excellence", um concurso de qualidade de cafés de todo o Brasil, promovido pela Associação Brasileira de Cafés Especiais. Esse evento traz para o Sul de Minas, profissionais e executivos de diversas partes do mundo, o que credencia o café da região a participar de leilões internacionais em que os valores comercializados por saca superam em muito o valor do café tradicional (BLISKA et al., 2007).

Não menos importância foi dada à possibilidade da divulgação das regiões onde o café especial é cultivado. O permanente contato dessas regiões com agentes nacionais e internacionais ligados ao setor do café promove o incremento do fluxo turístico, quer por motivo de lazer, quer por motivos de negócios, ou científicos (CAFÉ COM TURISMO, 2009).

No ano de 2004, aconteceu à primeira feira nacional organizada pela Associação Brasileira de Turismo Rural (Abratur), que tem a tarefa de coordenar todas as ações ligadas, ao turismo de campo no Brasil. A associação nacional está ganhando representatividade, criando as associações estaduais e as municipais, todas interligadas entre si. A cultura local é o principal fator de agregação de valor aos produtos de certa região. Por isso, pode-se trabalhar para gerar um diferencial que pode tornar a base do desenvolvimento do turismo sustentável (ABRATUR, 2009).

A rota do café especial é um exemplo expressivo de turismo rural na cafeicultura do Sul de Minas Gerais, que acontece no município de Carmo de Minas. Esta rota proporciona aos turistas atrativos e atividades ímpares, como conhecer o processo de produção e rastreabilidade do café, percorrendo a Fazenda Sertão, local propício para a produção de Cafés Gourmet, por reunir características naturais como micro-clima de montanha, solo e temperatura apropriados, estações bem definidas, e elevada altitude (de 1.000 a 1.500 m), faz com que Carmo de Minas seja umas das 
cidades mais visitadas por especialistas e apaixonados por cafés especiais (ROTA DO CAFÉ ESPECIAL, 2009).

Nesta rota, os turistas participam de passeios com caminhadas pelas lavouras, visitas ao pátio de secagem, paradas em mirantes de elevadas altitudes, visitas monitorada com breves explicações de toda a cadeia produtiva do café especial, degustação do café que hoje é comparado aos melhores vinhos do mundo, em um típico casarão colonial, que hoje funciona como museu (ROTA DO CAFÉ ESPECIAL, 2009).

Segundo Andrade (2010) as novas tendências de consumo, que claramente privilegiam o consumo que busca uma experiência e um valor simbólico, abandonam o valor estritamente comercial de produtos como o café, apontando o turismo e a gastronomia como práticas muito recorrentes e valorizadas na contemporaneidade.

Andrade e Moss (2012) mostram que a Colômbia, país que também se caracteriza pela cafeicultura de montanha e de base familiar como grande parte do Sul de Minas, tomou a frente e transportou para o turismo o universo da cafeicultura, tornando-se um país conhecido como produtor dos melhores cafés do mundo. Acredita-se que na região Sul do estado de Minas Gerais é possível trilhar, de forma sustentável, este caminho do Turismo do café.

\section{O município de Poço Fundo (RS) e a Perspectiva do Turismo Rural}

O município de Poço Fundo está localizado na bacia do Rio Grande, mais especificamente, no médio Rio Grande, região Sul do Estado de Minas Gerais, entre as coordenadas $21^{\circ} 46^{\prime} 51^{\prime \prime} \mathrm{S} 45^{\circ} 57^{\prime} 54^{\prime \prime} \mathrm{O}$, conforme mostra a Figura 1 . A altitude do município varia entre 885 e 1435 metros, com uma pluviosidade média de 1592,7 mm/ ano. O município apresenta características do bioma Mata Atlântica e "mar dos morros" é o nome designado ao relevo, que é ondulado (60\%), e com áreas montanhosas (40\%). As características de solo e relevo variam no município, o que permite certa diferenciação nas atividades agropecuárias (GONÇALVES, 2003), entretanto prevalecem os solos classificados como Latossolos, Podzólicos e Hidromórficos.

Poço Fundo teve ouro lavrado a céu aberto, debaixo da terra ou em águas correntes no tempo da exploração colonial, hoje sua fonte de riqueza é o café. A cultura de café representa $48,4 \%$ do total da área cultivada no município (IBGE, 2010). Poço Fundo faz parte, desse terreno fértil de produção cafeeira (RAMOS, 2008).

De acordo com o censo demográfico do IBGE (2010), em Poço Fundo predominam pequenas propriedades agrícolas de base familiar, sendo que $49,4 \%$ dos estabelecimentos possuem área total de até 10 ha. Dos quase 16.000 habitantes de Poço Fundo, 41,80\% residem no meio rural.

Gonçalves (2003) realizou um levantamento da área rural de Poço Fundo que constatou que a mesma foi dividida em aproximadamente 40 bairros, conforme suas características e história. Cada um com suas peculiaridades como ambiente natural, manifestações religiosas, laços familiares, e até pequenos centros comerciais. Em

Página 1003 Revista Brasileira de Ecoturismo, São Paulo, v.6, n.5, nov 20I3-jan 20I4, pp.990-I0I5. 
alguns bairros rurais deste município ocorrem manifestações religiosas como a Reza da Cruz e a festa de São José Operário e Nossa Senhora em Dourado dos Lopes; a Mãe Rainha em diversas comunidades, como Cardoso; os grupos de reflexão, cultos e missas. São manifestações calcadas em afinidade de parentesco e de vizinhança, que causa uma dinâmica própria a cada bairro rural.

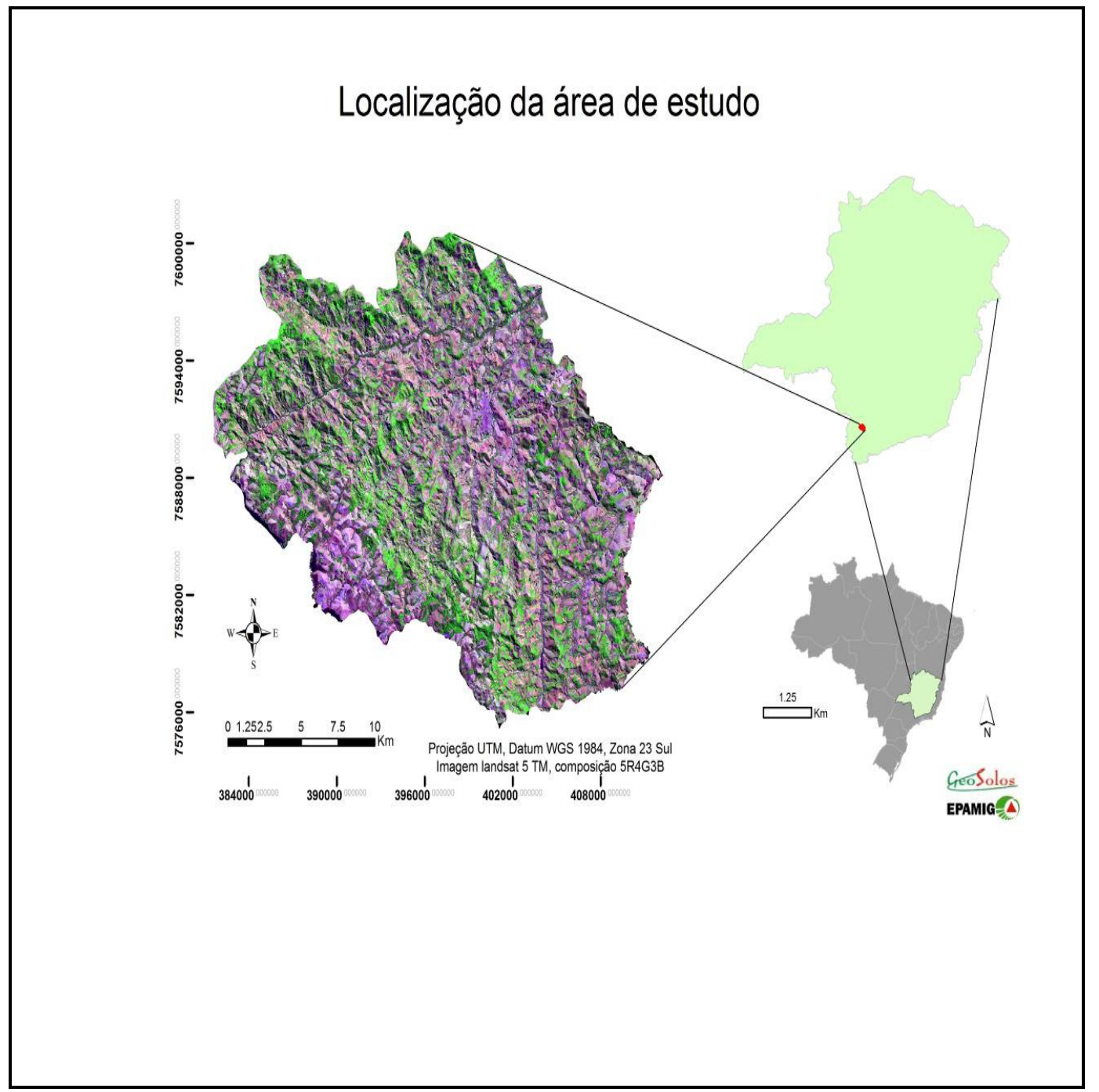

Figura 1: Mapa de localização do município de Poço Fundo no estado de Minas Gerais, Brasil. Fonte: Epamig.

Figure 1: Location of the municipality of Poço Fundo in the state of Minas Gerais, Brazil. Source: Epamig.

Parte dos agricultores utiliza como meio de transporte, carros, bicicletas ou carroças. As culturas agrícolas encontradas mais comumente são: café, milho, arroz, fumo, feijão e hortaliças. Os animais mais comuns para criação são: galinhas, suínos e bovinos. A alimentação para consumo, basicamente é arroz, feijão, algumas verduras e legumes, as carnes que são de criação própria são consumidas com menor frequência. Quitandas, como bolos de fubá, biscoitos amanteigados, também 
fazem parte do consumo dos agricultores familiares de Poço Fundo (GONÇALVES, 2003).

Com o intuito de se caracterizar as áreas ocupadas pela cafeicultura na paisagem do município de Poço Fundo e avaliar como estas áreas estão distribuídas em relação ao relevo, foi realizada uma consulta ao Banco de Dados Geográfico do laboratório GeoSolos, da Unidade Regional Sul de Minas da EPAMIG, localizado no Campus da Universidade Federal de Lavras. A Figura 2 apresenta o mapa temático de Uso e Ocupação da Terra de Poço Fundo. As áreas cafeeiras ocupam 18\% da área total do município. Observa-se também que as áreas com mata são bem extensas, perfazendo $20 \%$ da área total, o que confere a esta região características peculiares para o desenvolvimento do turismo rural sustentável.

\section{Mapa de uso do solo do municípío de Poço Fundo, MG}

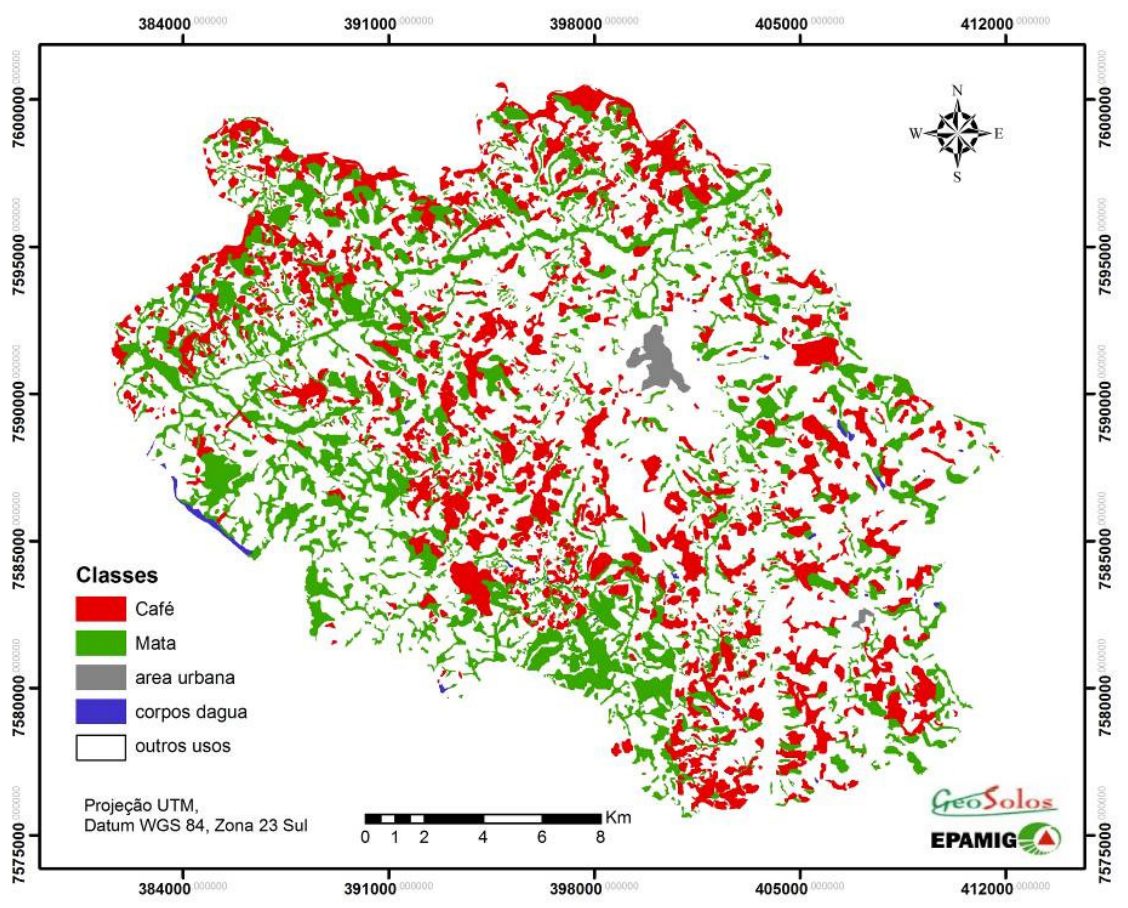

Figura 2: Mapa de uso do solo de Poço Fundo, 2007. Fonte: Epamig/GeoSolos.

FIGURE 2: Soil use map of the municipality of Poço Fundo, 2007. Source: Epamig / GeoSolos

A Tabela 1 apresenta a distribuição do café em relação às classes de relevo mapeadas no município. Verifica-se que a cafeicultura concentra-se nos relevos ondulado a forte ondulado, sendo 3.641 ha ou aproximadamente $45 \%$ na classe de relevo ondulado e 3.455 ha ou aproximadamente $43 \%$ na classe de relevo forte ondulado, totalizando quase $88 \%$ das áreas de café. 
Souza, K.R.; Borém, R.A.T.; Alves, H.M.R.

Tabela 1: Áreas Cafeeiras distribuídas por classes de relevo no município de Poço Fundo (MG).

Table 1: Coffee areas distributed by relief classes of the municipality of Poço Fundo (MG, Brazil).

\begin{tabular}{|l|r|r|}
\hline Café nas diferentes classes de relevo & \multicolumn{1}{c|}{ ha } & \multicolumn{1}{c|}{$\%$} \\
\hline Café/Plano & 155 & $2,0 \%$ \\
\hline Café/Suave Ondulado & 795 & $9,7 \%$ \\
\hline Café/Ondulado & 3641 & $44,8 \%$ \\
\hline Café/Forte Ondulado & 3455 & $42,5 \%$ \\
\hline Café/Montanhoso & 80 & $1,0 \%$ \\
\hline TOTAL & $\mathbf{8 1 2 6}$ & $\mathbf{1 0 0} \%$ \\
\hline
\end{tabular}

Fonte: Epamig. Source: Epamig.

Desde que associado a um sistema de manejo adequado, Poço Fundo apresenta fatores ambientais favoráveis à produção de cafés de excelente qualidade de bebida, tais como altitudes elevadas e áreas com vegetação nativa preservada (Figura 3).
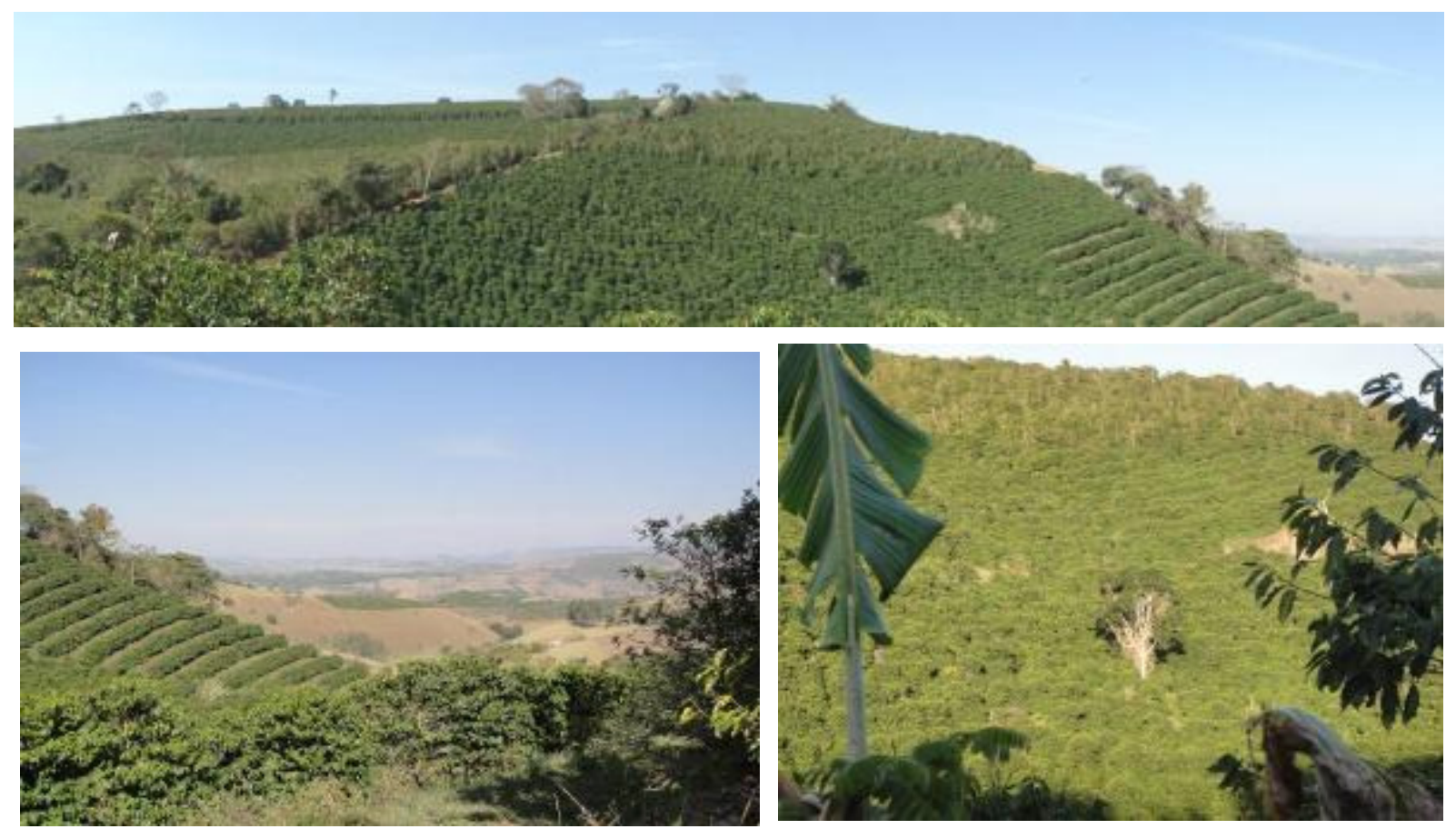

Figura 3: Paisagem Rural da região de Poço Fundo, MG. Foto: Joel Schuler (2012).

Figure 3: Rural Landscape the region of Poço Fundo, MG. Photo: Joel Schuler (2012). 
Observa-se no momento uma crescente busca por cafés especiais tanto no mercado internacional quanto no mercado interno. Poço Fundo possui características ambientais favoráveis para atender este mercado consumidor, enquanto outras regiões tradicionalmente produtoras não possuem estas vantagens

A Figura 4 ilustra a área urbana do município de Poço Fundo, enquanto a Figura 5 procura retratar aspectos da Agricultura familiar na região.

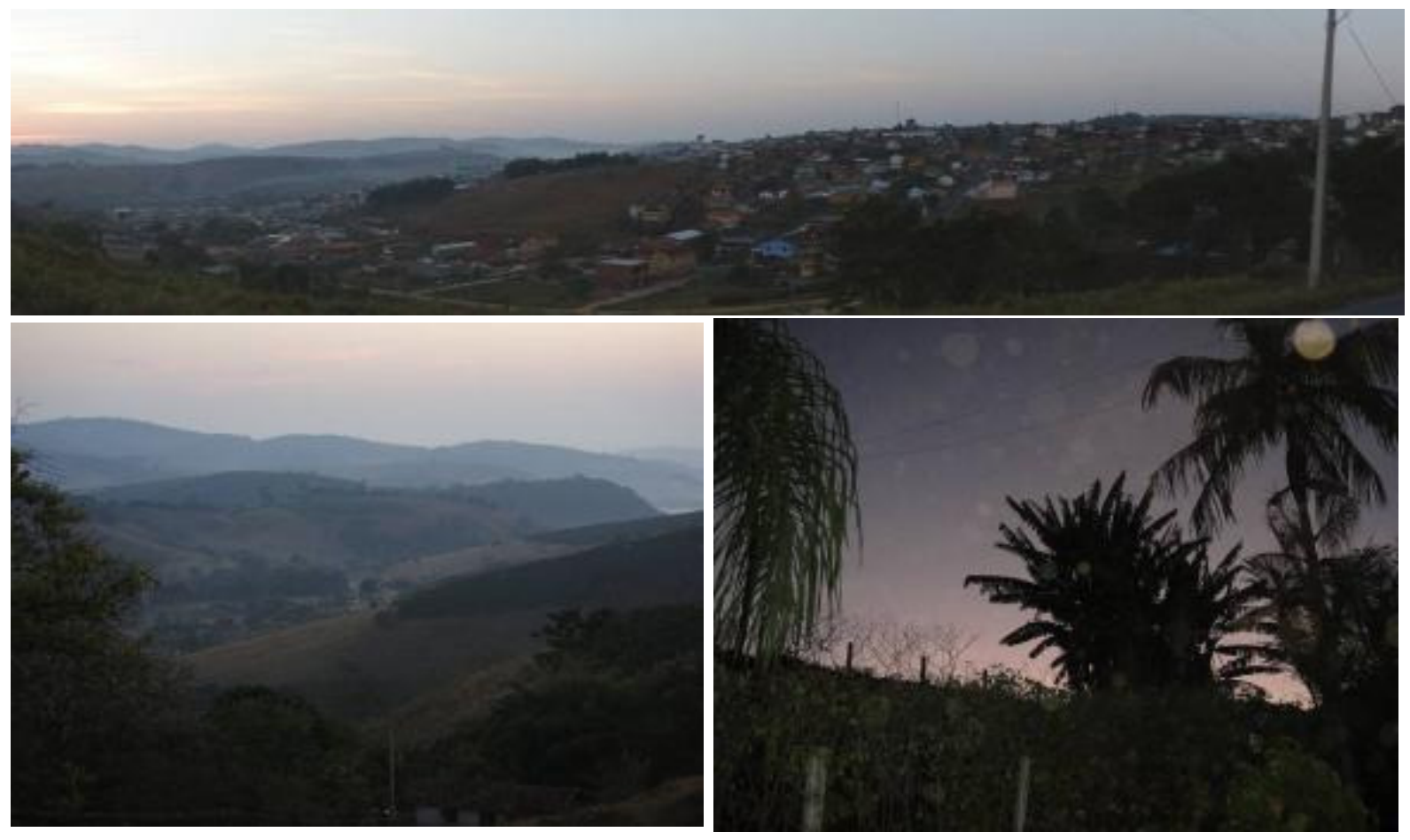

Figura 4: Área urbana do município de Poço Fundo (MG). Foto: Joel Schuler (2012).

Figure 4: Urban area of the municipality of Poço Fundo (MG, Brazil). Photo: Joel Schuler (2012).

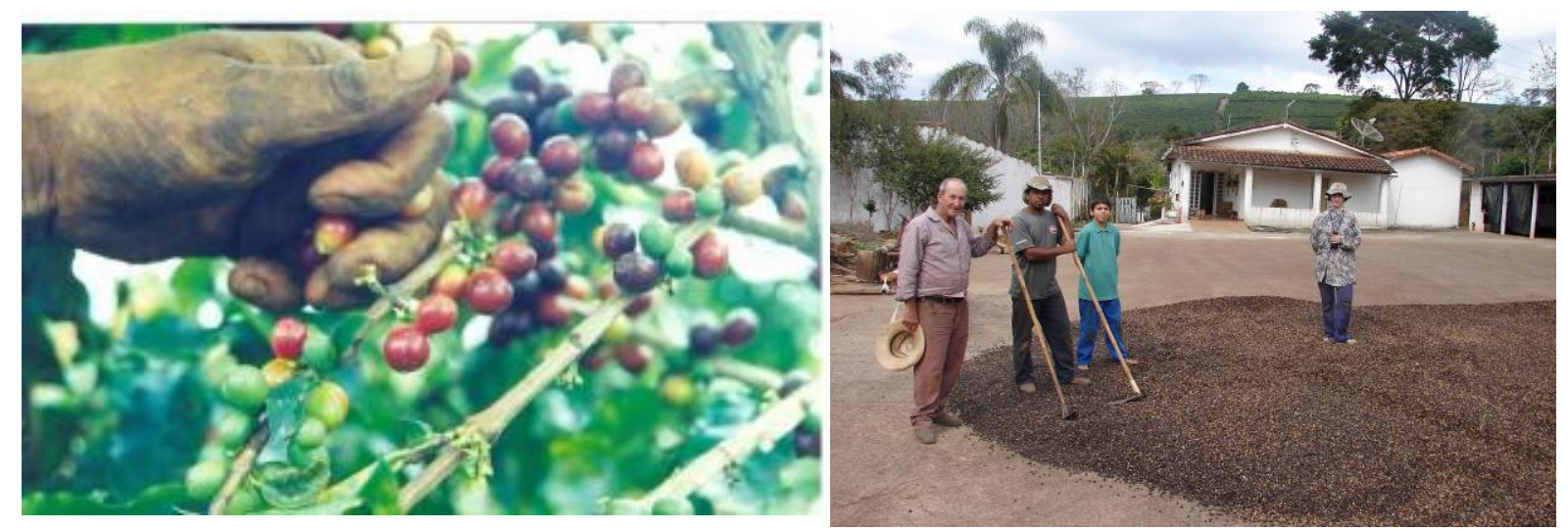

Figura 5 - Agricultura familiar na região de Poço Fundo (MG). Foto: Cibele Aguiar (2012).

Figure 5 - Family farms of the municipality Poço Fundo (MG, Brazil). Photo: Cibele Aguiar (2012). 
Aliada as condições edafoclimáticas excelentes para a produção de cafés de qualidade, a região adota técnicas ecologicamente corretas para a sua produção praticando amplamente a agricultura orgânica. $\mathrm{Na}$ visão dos agricultores de Poço Fundo a agricultura orgânica proporciona um estilo de vida diferenciado para aqueles que estão envolvidos no processo, ocorrendo em diferentes dimensões.

Em todas as atividades humanas, o fazer de forma ecológica é um questionamento atual e está inserido, desde a elaboração até a gestão do projeto, em todas as suas interfaces socioeconômicas, culturais e físico-ambientais. Sob essa ótica, a sustentabilidade do processo produtivo não passa somente pelo balanço positivo no caixa da empresa. É preciso considerar o aspecto ecológico em que consistem o uso e a preservação dos recursos naturais (REVISTA CAFEICULTURA, 2009).

Assim, a agricultura orgânica significa um novo modelo de desenvolvimento, uma nova filosofia de produção agrícola, a necessidade de se produzir um alimento que nutra, refaça efetivamente e se torne o combustível do corpo. Uma nova mentalidade no campo vai se estabelecendo junto à conscientização do agricultor e mudando a vida dos agricultores.

Dentro da agricultura orgânica vemos a potencialidade para a exploração do turismo rural já que grande parcela da sociedade preocupa-se em ter uma alimentação saudável o que torna cada vez mais visível a importância deste elo entre o turismo e a agricultura orgânica, garantindo assim o sucesso das propriedades e integrantes (STANGE; ARAUUO, 2005). Com as crescentes exigências dos mercados de que os alimentos produzidos não sejam portadores de agrotóxicos, a reciprocidade entre turismo em áreas rurais e a agricultura orgânica vem garantindo o sucesso das propriedades que exploram ambas as atividades.

A agricultura orgânica valoriza a propriedade, aumenta a renda familiar, serve como atrativo para promover o deslocamento do turista do seu local de residência fixa e serve de referência para despertar o interesse dos pesquisadores (SEBRAE, 2002). Ela incorpora todas as variáveis ambientais no processo de produção, portanto, por comparação, se qualquer análise dos impactos ambientais numa propriedade rural agroturística for positiva, poder-se- á inferir que se aquela propriedade praticasse a produção de alimentos dentro do processo orgânico, os impactos naturalmente seriam favoráveis e possivelmente mais significativos (SCIALABBA; HATTAM, 2002).

Essa relação turismo $x$ agricultura orgânica pode trazer vantagens não apenas agregando valor aos produtos agrícolas, mas induzindo o surgimento de indústrias artesanais, possibilitando, por sua vez, a geração de vários serviços na comunidade receptora. Um trabalho realizado em propriedades com agricultura naturalmente diversificada, associada a um ambiente saudável, organizado e ampliado por um roteiro de visitação, pode transformar estes em locais de descanso, lazer, apreciação paisagística, ou até mesmo num parque recreativo (STANGE; ARAÚJO, 2005). 


\section{Considerações Finais}

Buscou-se analisar as perspectivas do turismo rural associado à cafeicultura familiar e identificar a potencialidade do turismo rural para a região de Poço Fundo, sul de Minas Gerais.

Os resultados evidenciaram que visíveis problemas como o abandono das atividades do campo, a perda das tradições, dificuldade de comercialização dos produtos, podem ser amenizados pelo acréscimo do Turismo rural, gerando emprego e renda. Esse segmento surge como uma das principais atividades do campo, devido à crise no setor cafeeiro nos últimos tempos, podendo ser uma fonte de renda alternativa, mas de grande importância, para os dos cafeicultores familiares. Contudo, é primordial manter as atividades já existentes, aprimorá-las e acrescentar outras que agreguem valor ao segmento e gere melhorias. Para isso é necessário maiores investimentos em pesquisas, elaboração de projetos, apoios governamentais e locais. Há algumas limitações em relação a esta atividade, dentre as quais podemos citar: dificuldade de financiamento, pessoas especializadas, capacidade de gerir, disponibilidade de horário por parte dos proprietários, entre outros.

Porém, fazendo um planejamento coerente os benefícios serão maiores, como a possibilidade de aumentar a renda do produtor, gerar emprego direto e indireto, fortalecer a economia local, promover o intercambio entre o turista e os agricultores familiares, desestimular o êxodo rural, entre vários outros benefícios. Buscar apoio financeiro para a criação de hotéis, restaurantes, rotas turísticas e associações, o estabelecimento da Indicação Geográfica na modalidade de Indicação de Procedência para o café do território.

A região de Poço Fundo tem potencialidade para o desenvolvimento do Turismo Rural. É possível estabelecer nesta região uma "Rota do Café" (agricultura familiar, café orgânico), semelhante a "Rota do Café Especial" de Carmo de Minas (MG). Todos os agricultores envolvidos no processo têm que se tornar "pluriativos", ou seja, combinar as atividades agropecuárias com o atendimento aos turistas.

Para maior conhecimento de Poço Fundo o presente trabalho caracterizou ambientalmente as áreas do município em uso da terra e áreas cafeeiras distribuídas por classes de relevo, verificando-se então, que as condições ambientais são extremamente favoráveis para a produção de cafés gourmets, como produto turístico, com características edafoclimáticas favoráveis, receptividade local, cultura e demais atrativos.

Assim, este conjunto de quesitos possibilitaria a manifestação de iniciativas promissoras para a constituição de alternativas de qualidade frente ao modelo agro alimentar dominante no Brasil. Essas condições configurar-se-ão em uma reestruturação das concepções de desenvolvimento, principalmente quando associadas às preocupações com o equilíbrio da ocupação territorial, com a criação de empregos, a garantia de geração de renda para a reprodução social da agricultura familiar e com o desenvolvimento de um destino turístico de produção, potencialização e favorecimento das múltiplas funções da agricultura (ambiental, social, econômica e cultural). 


\section{Referências bibliográficas}

ABRAMOVAY, R. Agricultura familiar e desenvolvimento territorial. Revista da Associação Brasileira de Reforma Agrária, (28): 1, 2, 3 e (29): 1 - jan/dez 1998.

ALVES, J.M.; PAGLIARUSSI, M.S. O fenômeno do agroturismo e a influência das instituições no desenvolvimento econômico local: um estudo de caso na Região Centro-Serrana do Espírito Santo. Simpósio FUCAPE de Produção Científica, 4. 2006, Vitória. Anais... Vitória: FUCAPE, 2006.

ANDRADE, H.C.C. O café especial como produto turístico gastronômico: reflexões sobre o café especial e suas interfaces com o turismo. Monografia. Belo Horizonte: UFMG, 2010.

ANDRADE, H.C.C.; MOSS, M.C.B. A cafeicultura familiar e um possível modelo para o desenvolvimento do turismo do café em Minas Gerais. Revista Brasileira de Ecoturismo, São Paulo, v.5, n.3, set/dez, pp. 512-529. 2012.

ASSOCIAÇÃO BRASILEIRA DA INDÚSTRIA DO CAFÉ (ABIC). Disponível em: $<$ http://www.abic.com.br/export asetorial.html>. Acesso em 18 Jun. 2009.

ASSOCIAÇÃO BRASILEIRA DA INDÚSTRIA DO CAFÉ (ABIC). Disponível em: $<$ http://www.abic.com.br/export asetorial.html>. Acesso em 25 de Maio. 2012.

ASSOCIAÇÃO BRASILEIRA DE TURISMO RURAL (ABRATUR): Disponível em: $<$ http://www.etur.com.br/ conteudocompleto.asp?|IDConteudo=122/>. Acesso em 08 jul. 2009.

BARBOSA, J.N.; BOREM, F.M.; ALVES, H.M.R.; VOLPATO, M.M.L.; SOUZA, V.C.O.; SANTOS, W.J.R.; ANDRADE, L.N. Distribuição espacial de cafés do estado de Minas Gerais e sua relação com a qualidade. Simpósio de Pesquisa dos Cafés do Brasil, Vitória, 2009. Anais... Vitória: Embrapa, 2009.

BENI, M. Análise estrutural do turismo. São Paulo: SENAC, 1998.

BLISKA, F.M.M.; PEREIRA, S.P.; GIOMO, G.S. Mercados para o café certificado. Revista do grão à xícara, Campinas (SP), Instituto Agronômico de Campinas IAC. p.39-51, 2007.

BRASIL. Ministério do Turismo. Diretrizes para o desenvolvimento do turismo rural. Esplanada dos Ministérios: Brasília, 43p, 2004.

BRAZIL SPECIALITY COFFEE ASSOCIATION (BSCA). Cafés especiais. Disponível em: <http://www.bsca.com.br>. Acesso em: 23 nov. 2008.

CAFÉ COM TURISMO. Disponível em: <http://cafecomturismo.blogspot.com/>. Acesso em 25 jun. 2009. 
CARNIELLI, P.; MELO, E.V. Impactos dos cafés especiais no turismo. In: Impactos sobre o turismo no Espírito Santo. Vitória: SEBRAE/ES, 121p, 2005.

CARVALHO, Y. M. C. Importância da agricultura familiar para o Brasil. Informe Agropecuário, Belo Horizonte, v.30, p. 7-15, 2009.

CAVACO, C. Turismo rural e desenvolvimento local. São Paulo. Anais... Turismo e geografia. São Paulo: Hucitec, p.94-121, 2001.

COELHO, F.M.G. O café em um outro retrato do Brasil rural: o lugar da agricultura familiar. Informe Agropecuário, Belo Horizonte, Edição especial, v.26, p. 9-16, 2005.

COMPANHIA NACIONAL DE ABASTECIMENTO (CONAB): Disponível em: $<$ http://www.conab.gov.br/conabweb/download/safra/estudo safra.pdf.> Acesso em: 25 de maio. 2012.

COOPER, C.; FLETCHER, J.; GILBERT, D.; WANHILL, S. Tourism: Principles and Practice. Longman: Harlow, Ingland. 1996.

COOPERATIVA DOS CAFEICULTORES DE CAMPOS GERAIS E CAMPO DO MEIO (COOPERCAM). Disponível em: <http://www.coopercam.com.br/ noticia detalhes.asp?id=8>. Acesso em: 7 jul. 2009.

CORNER, D.M.R. Introdução ao turismo. São Paulo: Roca. 2001.

DENARDI, R. Agricultura Familiar e Políticas Públicas: alguns dilemas e desafios para o desenvolvimento rural sustentável. Disponível em: <http:// www.emater.tche.br/docs/agroeco/revista/ano2 n3/revista agroecologia ano2 num3 parte12 artigo.pdf>. Acesso em: 20 jun. 2009.

ECOPARANÁ. Disponível em: <http://www.ecoparana.pr.gov.br/ecoparana/>. Acesso em: 15 jul. 2009.

FERNANDES, A.E.B. Disponível em: <http://www.webartigos.com/articles/ 16496/1/o-perfil-da-agricultura-familiar-brasileira/pagina1.html>. Acesso em: 2 jul. 2009.

GOMES, M.F.M.; ROSADO, P.L. Mudança na produtividade dos fatores de produção da cafeicultura nas principais regiões produtoras do Brasil. Revista de Economia e Sociologia Rural, v. 43, n. 4, p. 353-378, out/dez 2005.

GONÇALVES, A. Agroecologia, saber local e mercado: um estudo sobre a agricultura familiar de Poço Fundo-MG. 2003. Dissertação (Mestrado em Administração - Gestão Social, Ambiente e Desenvolvimento) - Universidade Federal de Lavras, Lavras, 2003.

INSTITUTO BRASILEIRO DE GEOGRAFIA E ESTATíSTICA (IBGE). Censo demográfico 2010. Rio de Janeiro: 2010. 
KHATOUNIAN, C.A.; SOARES-JÚNIOR, D. Abordagem sistêmica e pesquisa participativa na agricultura familiar: ferramentas para o desenvolvimento. Informe Agropecuário, Belo Horizonte, v.26, p. 17-27, 2005.

KOTLER, P. Administração de marketing: Análise, Planejamento, Implementação e Controle. 5.ed. São Paulo:Atlas,1998.

LAGE, B.H.G.; MILONE, P.C. Fundamentos econômicos do turismo. São Paulo. Anais... Turismo. São Paulo: Atlas, p. 25-37, 2000.

LAMARCHE, H. A agricultura familiar: comparação internacional. Traduzido por Ângela Maria Naoko Tijiwa. Campinas: Editora da UNICAMP, 1993. (Coleção Repertórios). (Tradução de: L'agriculture familiale).

LIMA FILHO, D.O.; MAIA, F.S.;SPROESSER, R.L.; GONCALVES, A.F.; AMARAL, G.P.G.; SANTOS, A.M.; O turismo rural e o pequeno agricultor (15 páginas). XLII Congresso da Sociedade Brasileira de Economia e Sociologia Rural, 2004, Cuiabá. Anais...Cuiabá, 2004.

MACHADO, G.B. Reforma agrária e multifuncionalidade do espaço rural. XLIII Congresso Brasileiro de Economia e Sociologia Rural, 43, Ribeirão Preto. Anais... Ribeirão Preto: SOBER, 2005.

MARQUES, E.R.; BOREM, F.M. ; PEREIRA, R.G.F.A. ; BIAGGIONI, M.A.M.; Eficácia do teste de Acidez Graxa na Avaliação da Qualidade do Café Arábica (Coffea arabica L.) submetido a diferentes período e temperatura de secagem. Ciência e Agrotecnologia, v.32, p.1557-1562, 2007.

MARTINS, M. Caracterização de sistemas orgânicos de produção de café utilizados por agricultores familiares em Poço Fundo-MG. 2003. Tese (Doutorado em Fitotecnia) - Universidade Federal de Lavras, Lavras, 2003.

MATTEI, L. Pluriatividade e turismo rural em Santa Catarina. In: Seminário do Turismo Urbano, 3 Campinas. Anais... Campinas, 2003.

MENDES, E.P.P. A produção rural familiar em Goiás: as comunidades rurais no município de Catalão (GO). 2005. Tese (Doutorado em Geografia) - Faculdade de Ciência e Tecnologia, Universidade Estadual Paulista, Presidente Prudente. 2005.

MENDRAS, H. Sociedades camponesas. Traduzido por M. J. da S. Lindoso. Rio de Janeiro: Zahar Editores, 1978.

MILONE, C.M.; MILONE, P.C. Perspectivas do turismo no terceiro milênio. São Paulo. Anais... Turismo. São Paulo: Atlas, p.353-372, 2000.

MINISTÉRIO DA AGRICULTURA, PECUÁRIA E ABASTECIMENTO (MAPA). Disponível em <http://www.agricultura.gov.br/>. Acesso em 13 set. 2009. 
MINISTÉRIO DO DESENVOLVIMENTO AGRÁRIO (MDA): Disponível em: < http:// www.mda.gov.br/portal/>. Acesso em: 08 jul. 2009

PEDINI, S. Certificação e comercialização de cafés da agricultura familiar. Informe Agropecuário, Belo Horizonte, v.26, Edição Especial, p. 118-124, 2005.

PIN, J.V.; CARNIELLI, P. Impactos do turismo no espaço rural. In: Impactos sobre o turismo no Espírito Santo. Vitória: SEBRAE/ES, 121p, 2005.

RAMOS, R.V. Saber de experiência feita e conhecimento científico no processo de produção do saber apropriado: a experiência da Associação de Pequenos Produtores de Poço Fundo - MG. 2008. Tese (Doutorado em Gestão Social, Ambiental e Desenvolvimento) - Universidade Federal de Lavras,Lavras, MG. 2008.

REVISTA CAFEICULTURA: Disponível em: <http:// www.revistacafeicultura.com.br/index.php?tipo=ler\&mat=22073\&produt ores-depoco-fundomg-investem-em-cafe-organico>. Acesso em: 10 jul. 2009

RIBEIRO, A.C.; GUIMARÃES, P.T.G.; ALVAREZ, V.V.H. (ed.). Recomendações para o uso de corretivos e fertilizantes em Minas Gerais, 5a aproximação. CFSEMG: Viçosa, 359p, 1999.

ROTA DO CAFÉ ESPECIAL: Disponível em: <http:// www.rotadocafeespecial.com.br/>. Acesso em: 05 jun. 2009.

SAQUET, M.A. Campo-Território: considerações teórico-metodológicas. Revista Geografia Agrária, Uberlândia, v.1, n.1, p.60-81, fev. 2006. Disponível em: <http:// www.ig.ufu/campoterritorio/>. Acesso em: 10 de maio. 2009.

SEBRAE-ES, Vitória, n. 2, p. 115, dez. 2001/jan. 2002.

SCHUCH, H.J. A importância da opção pela agricultura familiar. Disponível em: $<$ http://gipaf.cnptia.embrapa.br/itens/publ/fetagrs/fetagrs99 >. Acesso em: 03 de maio. 2009.

SCIALABBA, N.E.; HATTAM, C. Segurança orgânica da agricultura, do ambiente e do alimento. Roma: FAO, 2002.

SHEYVENS, R. Tourism for development: empowering communities. Harlow, England: Pearson Educational, 2002.

SILVA, J.G. As novas atividades no meio rural. Campinas. Anais... O novo rural brasileiro. Campinas: UNICAMP, p. 90-100, 2002.

SILVEIRA, M.A.; MORUZZI MARQUES, P.E. Tendências em torno das referências de qualidade alimentar e seus impactos nas dinâmicas territoriais: o caso da cafeicultura familiar no sul de Minas Gerais. Simpósio de Pesquisas dos Cafés Brasil, Vitória, ES. Anais... Brasília, DF: Embrapa Café, 2009. 
STANGE, A.; ARAÚJO, J.B.S. Impactos da agricultura orgânica no turismo. In: Impactos sobre o turismo no Espírito Santo. Vitória: SEBRAE/ES, 121p, 2005.

TAGLIARI, P.S.; FRANCO, H.M. Turismo rural: 52 safras por ano. Agropecuária Catarinense, Santa Catarina, v.7, n.4, p.14-20, 1994.

TEIXEIRA, A. A. Café brasileiro, a marca forte da nossa bebida. Campo e negócios, v 64, p. 39-45, Uberlândia - MG, 2008.

TONIETTO, J. Geographical indicators for grapes. Acta Horticulturae, v. 785, p. 467-476, 2008.

TORGA, P.A.A. Novas ruralidades e a Rota do Café Especial, no município de Carmo de Minas. Monografia. Conselheiro Lafaiete: UFMG, 2011.

TURISMO RURAL NA AGRICULTURA FAMILIAR (TRAF). Disponível em: < http:// www.redetraf.com.br/r-rede-traf.asp>. Acesso em: 08 Jul. 2009.

VIEIRA, T.G.C.; ALVES, H.M.R.; VOLPATO, M.M.L.; SOUZA, V.C.O. Caracterização ambiental de regiões cafeeiras para Indicação Geográfica. In: REIS, P.R.; CUNHA, R.L.; CARVALHO, G.R. (Eds.) Café Arábica da póscolheita ao consumo. Vol. 2. Lavras: EPAMIG, 2011. p.591-639.

ZANDONADI, B.M.; FREIRE, A.L.O. O meio rural como atrativo para o agroturismo em Venda Nova do Imigrante (ES): o caso da família Carnielli. Seminário de Pesquisa em Turismo do Mercosul, 7, 2012, Caxias do Sul. Anais... Caxias do Sul:UCS, 2012. p.1-16.

ZANELLA, V. Avanços na Indicação Geográfica de Vinhos na Serra Gaúcha. Disponível: $\quad$ <http://www.embrapa.br/embrapa/imprensa/noticias/2008/ dezembro/1a-semana/avancos-na-indicacao-geografica-de-vinhos-na-serragaucha>. Acesso em 04 dez. 2008.

WANDERLEY, M.N.B. Raízes históricas do campesinato brasileiro. In: TEDESCO, J.C. (org). Anais... Agricultura familiar: realidades e perspectivas. Passo Fundo: UPF, p. 23-56,1999. 
Katiane Ribeiro Souza: Universidade Federal de Lavras, Lavras, MG, Brasil.

Email: katianerib@hotmail.com

Link para o currículo Lattes: http://lattes.cnpq.br/4513832044913445

Rosângela Alves Tristão Borém: Universidade Federal de Lavras, Lavras, MG, Brasil.

Email: tristao@dbi.ufla.br

Link para o currículo Lattes: http://lattes.cnpq.br/6472336328549743

Helena Maria Ramos Alves: Embrapa Café (Empresa Brasileira de Pesquisa Agropecuária), Brasília, DF, Brasil.

Email: helena@epamig.ufla.br

Link para o currículo Lattes: http://lattes.cnpq.br/4766494058302983

Data de submissão: 31 de outubro de 2012

Data de recebimento de correções: 16 de julho de 2013

Data do aceite: 20 de setembro de 2013

Avaliado anonimamente

Página I0I5 Revista Brasileira de Ecoturismo, São Paulo, v.6, n.5, nov 20I3-jan 20I4, pp.990-I0I5. 